\title{
Beyond formal and informal: understanding urban informalities from Freetown
}

\begin{abstract}
Freetown challenges, even more than other cities, entrenched categories of formal and informal. In this paper, the discussion on informality encompasses both the distinction drawn between informal and formal settlements, and between informal and formal economic activities. It is difficult to speak without using these terms given that they are so deeply part of policy discourses in the country by government and development agencies. However, when deployed as an analytical lens, they are demonstrably problematic. Drawing from the findings of a research project, this paper provides insights on what the activities and spaces referred to in policy as "informal" are and what this classification does. It reveals the political use of the term informality, arguing that it is wrong to frame informality as belonging to the poor and challenging the idea that formality and informality are clearly distinct spaces or economic activities in the city. It also demonstrates the fundamental contribution of what policy makers call "informal" to the wellbeing and development of cities, by providing what the state and the "formal" sector are unable to provide: employment and social protection, particularly important for the post-conflict Sierra Leone context. The paper calls for a deep understanding of the contributions of the livelihoods of the residents of informal settlements and a change of criminalisation policies that undermine them.
\end{abstract}

\section{Keywords:}

Informality; informal settlements; informal economy; urban livelihoods; Freetown

\section{Introduction}

Freetown challenges, more than many other cities, the entrenched categories of formal and informal. Discourses about informality strongly shape visions of the city, and the policies and interventions which aim to transform the city. In this paper, the discussion on informality encompasses both the distinction drawn between informal and formal settlements, and between informal and formal economic activities. In Sierra Leone, it is difficult to speak without using these terms given that they are so deeply a part of the policy discourses of government and development agencies. However, when deployed as an analytical lens, they are highly problematic. Building on findings of a wider research project on the livelihood sectors that residents of Freetown's informal settlements are involved in, this paper provides insights on what the "informal" is and what it does. It aims to provide evidence to push policy makers to recognise the fundamental contribution of what they call "informal" to the wellbeing and development of cities, while questioning their dichotomous understanding of the formal-informal divide. This divide has been criticised but still matters because it is deployed politically in the discourse of government and other key actors, and drives urban policy in ways that produce injustices (Marx \& Kelling, 2019). Therefore, an empiricallygrounded challenge to such divide, demonstrating the effects of what informality does is an important undertaking to achieve more just and inclusive cities as part of the Sustainable Development Goal 11. The paper makes an original contribution in that it demonstrates the contradiction between discourses of informality and what informality is in practice, and the effects of this contradiction on the lives of urban residents. It also makes a strong argument for a change in policy towards informal livelihood activities which are currently criminalised 
and obstructed across cities in Africa. The paper does so by showing: the contradiction in the arbitrary categorisation of the informal; the international connections of some of these activities; the major contribution they offer to the city economy. The contribution is through the provision of key goods and services to formal economic activities as well as social security and employment to a large number or residents, while making up for limited state capacity by deploying complex hybrid forms of self-governance and self-regulations of these economic activities. This exploration of what informality does complements a growing body of work critically analysing the use of in/formality in the study of cities in the global South. A lot of this work has been looking at the political use of informality but for us the best way to theoretically challenge this use is to demonstrate the weakness of this analytical category while at the same time give centrality to the activities that are labelled "informal". The paper provides evidence to advocate against widespread policies that negatively affect informal livelihood activities in African cities, often underpinned by problematic visions of the city.

\section{Beyond formal and informal}

This paper challenges and complicates five key ideas about informality that are still dominant in policy circles, namely: 1) informal activities are not rule based; 2) the informal is distinct from the formal; 3) informality belongs to the poor; 4) informal activities are local, and mostly located in informal areas of the city; 5) changes to the informal sector only affects the wellbeing of those working in it. While some of these have been already criticised by a rich body of work, we problematise these ideas together through original empirical evidence which allows to build a strong argument and draw some important policy implications.

The formal is generally portrayed as "rule-based, structured, explicit, predictable" (McFarlane \& Waibel, 2012, p. 3), while the informal is considered to lack these characteristics. To go beyond normative definitions of the informal Guha-Khasnobis, Kanbur and Ostrom (2006) define informality as what is beyond the reach of official governance processes.

Both of these definitions imply a dichotomous understanding of formal and informal categories, which is challenged by a growing body of work that problematises the analytical use of this categorisation and explores its effects (Acuto, Dinardi, \& Marx, 2019; McFarlane, 2012; Roy, 2005). Conceptualising informality as strictly distinct from the "formal" fails to consider the "pervasiveness of informality within formal ways of doing things" (Myers, 2010, p. 9). Dichotomous and binary understandings rely on embedded hierarchies and an artificial divide (Marx \& Kelling, 2019), leading to the assumption of formality as the norm and informality as an exception that needs to be "repaired, fixed and corrected" (Acuto et al., 2019 , p. 483), which is particularly problematic in contexts such as Freetown where informality is dominant. Pratt argues that formality is the exception as "it is difficult to imagine a totally formal activity" as all activities escapes state control to some extent (Pratt, 2019, p. 614).

In fact informality has been considered a defining feature of African urbanism (Pieterse \& Simone, 2013) characterised by "economic informality, multiplicity, marginality and dispersion" (Parnell and Pieterse, 2014 cited in Dodman, Goosen, Rusca, \& Colenbrander, 2016). Acuto et al. (2019) argue for the need of adopting the concept of "informal urbanism" as an entry point to urban theorising that emerges from embedded contexts, calling for 
empirically-grounded theoretical contributions, focusing on the political dimensions of informality. Similarly, Banks et al. argues for an in-depth "political economy analysis of urban informality" that sees it as a "site for critical analysis" (2019, p. 1). Moreover, McFarlane (2019) argues for the need of convincing arguments about the need to consider informality beyond the dominant image of slums or precarious labour in the global South, and explore its forms in other realms.

What is labelled as informal is intrinsically linked to what is labelled as formal. Moreover, the 'informal' presents key characteristics of the formal and vice versa. This renders these categories linked, indistinct and politically loaded. For example:

"In African cities, informality is the norm with urban value chains and services containing formal and informal elements that are interdependent. Products and services may be delivered through chains with informal and formal stages, for example, and "formal" enterprises have informal practices, including informal employment of unskilled labour. In addition, employees in the formal sector rely on informal services to deliver productive work, such as transport and food stalls" (Rigon, Koroma, Macarthy, \& Apsan Frediani, 2018, p. 421).

Despite this fuzziness, categorisations of formal and informal are used to validate some type of businesses and people rather than others. Informal-formal categories become a "governmental tool" (McFarlane \& Waibel, 2012, p. 4) deployed by the state and other powerful actors, and a stream of the recent literature on urban informality focuses on the political application of these labels and the "technologies of categorisation" (Marx \& Kelling, 2019 , p. 498). As Ananya Roy (2009, p. 10) argues, informality does not "lie beyond planning; rather it is planning that inscribes the informal by designating some activities as authorised and others as unauthorised, by demolishing slums while granting legal status to equally illegal suburban developments." In this sense, government often criminalises the informality of the poor, while informal activities of wealthier groups are not even labelled as informal. Hence, a need to move the analysis beyond confining urban informality to the urban poor (Banks et al., 2019).

Despite the analytical and political challenges of the concept of informality, recent critical work has called for challenging widespread assumptions about the formal-informal divide but at the same time, recognising that, at the moment, the concept still has a productive role to understand cities (Acuto et al., 2019; McFarlane, 2019). In line with these works, we critically explore the use of the in-formal divide in policy and argue for an approach that investigates the economic activities of marginalised urban residents and how they are an organic and fundamental part of the city economy.

In this paper, we focus on informal economic activities (the economic dimension but also an organisational form) and informal settlements (a spatial dimension). In terms of economic activities, the informal sector is usually defined as employment and production that take place in unincorporated, unregistered, or small enterprises. The ILO estimates that the informal sector accounts for two-thirds (66\%) of non-agricultural employment in SubSaharan Africa (2018, p. 28). At the same time however, $77 \%$ of non-agricultural employment is recorded as taking place informally. These two different numbers mean that a significant amount-number of people are working in the so-called 'formal' sector, but in an 
informal way (employed as casual and undocumented labourers in a formal construction company, for example) (ILO, 2018, p. 28).

The informal economy has been broadly defined as "the diversified set of economic activities, enterprises, jobs, and workers that are not regulated or protected by the state" (ILO, 2002). The ILO's definition of informal employment (a key component of the informal economy), similarly focuses on employment which lacks social protection. However this broad definition throws up a number of problems. Echoing the reflections above, one of these is the extent to which boundaries between the formal and the informal can in practice be demarcated, due to a number of blurry lines. For example, economic activities may be regulated in some ways (e.g. taxation) but not in others (e.g. social protection of workers or quality control of output). Furthermore, even where economic activities are officially regulated by the state, this may not be applied in practice, drawing a distinction between formal regulation and de facto informality. In many contexts this de facto informality is accompanied by increasing informality of the de jure governance regimes. Linking these two processes Meagher notes in her analysis of informality in West Africa:

"Even states have become informalized as public officials govern in ways that contravene formal relations, and downsizing public sectors concede an increasing range of governance activities to community organizations" (Meagher, 2007, p. 406).

Another blurring of the boundaries can be found in the institutional and spatial 'sites' of informal economic activities. On the one hand, as illustrated by ILO's data above, much informal employment now takes place in what are considered to be formal enterprises (Williams \& Lansky, 2013). On the other hand, informal economic activities can be pervasive in formal areas of the city, while, equally, formal economic activities and employment may be based in informal settlements (e.g. official public employment of teachers or officials in slums). Not only informal activities are often wrongly considered as taking place in informal spaces but they are also deemed to be "local," an understanding that we will unpack by demonstrating its linkages with global value chains. The final idea we contest is that policies on the informal sector only affects the livelihoods and wellbeing of those working in this sector, a belief that lead to interventions that fail to acknowledge the wider role of the sector for the wellbeing of the city and country, particularly in urban Africa.

Recent scholarship (McFarlane \& Waibel, 2012) has interrogated the utility of the formal/informal urban divide and argued for the need of more work to explore the understudied formal-informal relation. This paper uses our empirical findings to contribute to this debate. Some of our findings relate to what the informal is and some to what the informal does. The latter both as a politically loaded concept but also, and more importantly, in terms of its material contribution to the city and its people. A key question raised by McFarlane and Waibel (2012, p. 1) is about "what work the notions of 'formal' or 'informal' do for different constituencies, including scholars, the state, non-governmental organisations, and so on". This more political question has led us to think about the strategic positioning of this research within policy discourses in Sierra Leone and Africa. 


\section{Methodology}

This paper builds on a wider research project undertaken by the XXXXX and XXXXX on the livelihoods of the residents of informal settlements. This project was developed on request of a network of NGOs working with informal settlement communities in Freetown, which rely on research undertaken by XXXXX to inform their interventions. The team worked with these stakeholders to identify four informal settlements amongst sixty-four settlements identified-as informal settlements in Freetown which formed the sampling frame. Prior to constructing the sample frame, a consultation session between XXX and other NGOs was undertaken in order to seek clarification about how settlements in Freetown are classified as informal settlements and the names and total number of informal settlements, including the actual location of such settlements in Freetown. This was followed by a field visit to nearly all the settlements to gather additional general information, including their precise location. Out of the sixty-four settlements, four settlement were selected through purposive sampling by applying the following criteria: diversity of settlement type and location, amount of existing knowledge on the settlement, and presence of development actors. Finally, two coastal settlements-Cockle Bay and Portee Rokupa-from the West and East of Freetown, respectively and two hillside settlements—Dwarzarck and Moyiba-from the West and East of Freetown were selected.

We agree with Narayan and Véron who explore production value chains as a way to understand how the city is produced thorugh interactions of formal and informal practices (Palat Narayanan \& Véron, 2018). Therefore, we selected specific value chains/livelihood systems in each of the settlements. We focused on sectors that characterised the settlements in that they were typical forms of livelihood and/or linked to the collective identity of the settlement, and they employed large numbers of people, specifically poorer residents. We further focused on sectors in which both women and men worked.

The project involved mapping key value chains in the four settlements, analysing flows of products, labour, money and other relations of support in each chain as well as the time allocated to different daily activities of women and men involved in each value chain, and their life histories. Twenty-six focus group discussions (FDG) with women and men working in different livelihood systems were conducted to map out the structure and the nature of the value chains. The discussions focused on an overall mapping of the nodes in the value chain, who participates in each node and how, the power relations and supporting structures and the impact on the wellbeing of those involved. An initial FGD was held to build an overall map of each value chain and then subsequent targeted FGDs were held with groups of workers from specific nodes in the chain.

Forty-four individual interviews were undertaken with women and men involved in different nodes in the value chains to record the activities that they undertook on the day before the interview. Twenty-seven interviews focused on the livelihoods life history of individual women and men involved in the different chains, focusing on why they entered this livelihood and how their participation in it has changed over the course of their career. We also structured the discussion to try to link career changes to changes in context (e.g. environmental changes, changes in rules and legislation, changes in land and property costs, infrastructure provision, etc.) or to changes in personal circumstances (e.g. family and household changes, migration, educational achievement, health issues). This was combined 
with a training workshop and pilot research sessions to build the research capacity of a number of urban stakeholders.

These methods were complemented with analysis of secondary sources as well as semistructured interviews with actors involved in the governance and support of these livelihood sectors. The paper also builds on a conference gathering researchers, communities, NGOs and policy makers to reflect on the synergies between informal and formal sectors in Freetown, and related policies which took place in August 2017. An outcome of this research process which also contributed to the reflections contained in this paper is a postgraduate course in Development and Planning in African cities for civil servants, academics and urban professionals in Freetown to rethink planning in light of the findings presented here. The trainings and conference were part of an attempt to collectively reflect about changing dominant understandings and discourses towards informality.

\section{What the "informal" is in Freetown}

Freetown is Sierra Leone's capital and main urban centre, housing approximately $20 \%$ of the country's seven million people. This Western region of Sierra Leone which includes Freetown has a population set to double in 16.5 years (Statistics Sierra Leone, 2015). Freetown's landscape is typically mountainous along a coastal line, which limits the spatial expansion of the city, forcing a growing low-income population to settle in less desirable land in precarious informal settlements. Freetown has grown significantly due to internal displacement during the civil war and economic migration (World Bank, 2013). Most migrants have settled in informal settlements because of their proximity to work opportunities and because land and housing are too costly for people who are predominantly employed in small-scale informal businesses. Depending on definition and categorisation, Freetown has between 27 and $64^{1}$ informal settlements, scattered along the coast and the hillsides. Some larger settlements along the coast function as small towns with complex internal economies and their own markets, small industries, and wharfs. Throughout Freetown's informal settlements, flooding, rock-falls, building collapse, and landslides are common, resulting in significant economic and other losses such as the destruction of property and infrastructure. The incidence of diseases and epidemics, especially those that are water-borne and linked to inadequate sanitation are a serious issue $(X X X X)$.

In Freetown what the definitions presented above would constitute as "informal" is the dominant urban form. For the spatial dimension, international definitions of informal settlements as unplanned settlements, not in compliance with planning and building regulations would label Freetown as being almost entirely informal. The 2014 Millennium Development Goals Indicators report of the United Nations Statistics Division (2015) estimated that $75.6 \%$ of the total urban population in Sierra Leone resides in areas classified as slums.

While we use both the terms slum and informal settlement in this paper we are aware that there is a contentious politics built around these terminologies. The term "slum" usually has derogatory connotations and thus its use can imply that a settlement needs replacement or can legitimate the eviction of its residents. However, sometimes it is a difficult term to avoid.

1 This is the figure we used for our baseline. 
First, the networks of informal neighbourhood organisations with whom we work choose to identify themselves with a positive use of the term 'slum' with the political aims of neutralising these negative connotations by re-appropriating the term, fostering slum dwellers as a collective identity, and appealing to international human rights legislation which refers to slum dwellers. Second, the only global estimates for housing deficiencies, collected by the United Nations, are for what they term "slums". Thirdly, given that many housing developments of the middle classes and urban elites meet many of the criteria of settlement informality (e.g. unclear tenure, lack of conformity with local government planning norms, and location on unsuitable land) it may be important to distinguish between these informal middle and high income settlements, and 'slums' as informal settlements of the poor.

Slums are defined by the UN as urban settlements with at least some of the following features: a lack of formal recognition of the settlement on the part of local government and its residents; the absence of secure tenure for residents; inadequacies in provision for infrastructure and services; overcrowded and sub-standard dwellings; and location on land less than suitable for occupation (UN-Habitat, 2003). Looking closely at this definition, and particularly in the context of Freetown, demonstrates that "informality" is not just a phenomenon of the poor. Taking a spatial perspective, for example, the last characteristic (living on land less than suitable for occupation) may be useful to understand the effects of the landslide of 2017 which killed a thousand people, including rich and poor households, who built their dwellings on land in a risk prone area. At the same time, this definition is too broad for Freetown and therefore a working group led by XXXXX worked on a local definition, which found consensus amongst several key stakeholders. Based on this, a slum in Freetown is an area in which:

- A significant proportion (over $60 \%$ ) of houses have insecure tenure;

- The majority of houses are semi-permanent structures (where semi-permanent means that it is built with materials including, but not limited to, card board and iron sheets also called 'pan body');

- Roads within the settlement are inaccessible for motor vehicles;

- Populations are highly vulnerable to risks including disaster and disease;

- The majority of residents are unemployed or are working in the informal sector where the informal sector is defined as businesses that either are not registered to pay taxes (not including market dues), or employ fewer than 6 people.

Equally, regarding the economic dimension, the broad definition of informality would encompass most of the economy. We reported some figures earlier but additionally, in the context of Sierra Leone, the high prevalence of self-employment and working for a family member makes up $87.7 \%$ of the labour force and - albeit not all family work is necessarily informal - it is a good proxy for informal employment.

Given that the focus of $X X X X X$ is the wellbeing of informal settlement residents (following local slum definition), our research focused on the livelihoods sectors of the informal settlement residents. This choice allowed to maintain the focus on a specific group of people and did not need to arrive at a commonly agreed definition of informal economic activities. As previously stated, while the categorisation of the informal and formal is problematic, in the context of Freetown it is difficult to avoid these categories as they are so embedded in 
policy discourses. Critically, they are often used as a "governmental tool" in order to label certain activities and localities as undesirable, and therefore in need of evictions/demolitions.

Livelihood activities of marginal residents of Freetown informal settlements, being moto taxi or street traders have faced abrupt bans and are perceived as a threat (Enria, 2018). The former Mayor's Foreword to the Freetown City Development Plan (Freetown City Council, 2016 , p. 6) states that "my major focus was to transform Freetown into a well-planned, modern, dynamic and vibrant metropolis". This sends a message which denies the value of the informal settlement constituting the majority of the city, suggesting that they are the result of bad planning, the antithesis of modernity, and characterised by a stagnating state of poverty. In Freetown, there is a deeply rooted criminalising discourse of the poor residents, particularly male youth, that goes back a century and is linked to a colonial modernity built on the exclusion of subaltern groups (Abdullah, 2002). In cities of the global South, it is not unusual to find civil servants and politicians expressing visions of city development concerned with processes of 'city beautification' or of urban regeneration, with aspirations towards the 'world class city' (Ghertner, 2011), that clashes with the reality and needs of most residents. The exclusionary nature of official urban visions in Africa has been underlined by many, and often includes the criminalisation of informal livelihoods activities (Brown, Lyons, \& Dankoco, 2010; Mitlin \& Satterthwaite, 2004; Watson, 2014). In Kigali, Finn (2018) describes a similar approach of authorities seeing informal vendors as dirty and incompatible with their modern vision of the city. Kamete (2012) argues that planners cannot cope with informality as it escapes their rigid binary classification of order/disorder legal/illegal they deploy to organise the city.

Such approaches typically deal with informal settlements through processes of eviction (Farha, 2011) typically justified either on the basis of the need to clear land to make space for infrastructure development (with land occupied by informal settlements normally the easiest to clear and the cheapest to acquire), or more directly with the rationale of eliminating informal settlements as intrinsically unruly or unsafe spaces, and a blight on city development (Bhan, 2009; Watson, 2009). It is also worth noting that while rationales for evictions of informal settlements are generally made on the basis of such 'public interest' arguments, the actual underlying motivations for the displacement of informal settlements (which are sometimes on central city land with high potential value) may also relate to private interests in profit through real estate speculation made possible by clearing the land of informal residents (at times in collusion with the state) (Lees, Shin, \& López-Morales, 2016; Oliver-Smith, 2010; Smith, 1996).

In Freetown, a key 'public interest' rationale for eviction occurs when an area is deemed to be risk prone. However, this label is often applied to large areas without careful consideration of which areas might, in fact, be habitable with mitigation measures. A similar approach can be seen in the case of street vending and other "informal" economic activities which may be labelled as informal and a nuisance to the city, while other activities and localities - equally informal from a point of view of formal regulations - are considered "desirable" and not labelled as informal. For example, a fishermen settlement was evicted because it was located on mangroves along the coast which is an environmental protected areas, however, the nearby expansion of hotels/restaurants on the same area continued undisturbed. 
Given their use by policy makers, the dismissal of the formal/informal classification is not easy. To counter "the different ways in which informality and formality are put to work [...] in the production of urban inequalities" (McFarlane \& Waibel, 2012, p. 7), we employ this classification to challenge its political use in calling for evictions and relocations by demonstrating the contribution of the livelihood sectors of the informal settlement residents.

We mapped where these sectors (see figure 1) bought their inputs and sold their products, which demonstrated how economic activities of informal settlement residents are connected with formal areas of the city and formal sectors of the economy. During training, by analysing the map, civil servants and other urban professionals concluded that interventions negatively affecting these livelihoods sectors would undermine the city economy.

We asked employees from government and other agencies to think about the services they needed in their everyday life to have a good life and productive work day. We then asked them to categorise these services between formal and informal. While they struggled with definitions given the informality within formality and vice versa, they acknowledged that they personally and heavily rely upon what is generally defined "informal" - a category they had been applied only to those activities which they had previously viewed as negative and to be curbed. This "everyday" understanding of urban informalities was very effective in shifting attitudes.

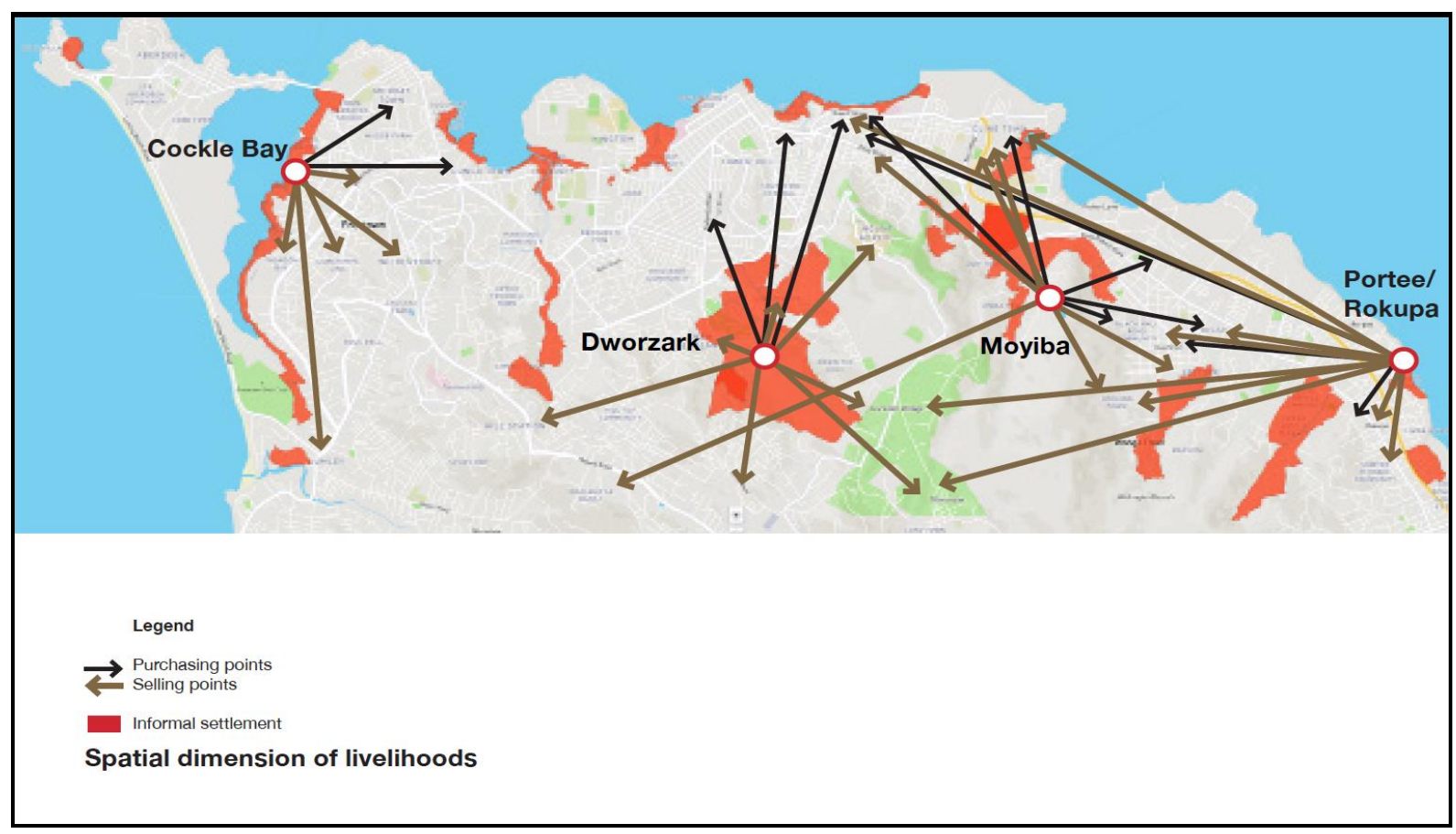

Figure 1: Relationships between livelihood sectors of informal settlement residents and the city

Evidence from our analysis challenges some established notions about the informal and corroborates the points made by the critical literature presented above. For example, large registered companies that import large volumes of second-hand clothes employ several informal workers and sometimes import clothes "informally" through the use of family 
diaspora networks. Telecommunications companies sell their mobile credit through a widespread network of informal traders able to reach every corner of the city.

Moreover, the livelihoods sectors in which informal settlement residents work, often viewed as 'local', are in fact part of complex global trade arrangements. In the informal settlement of Kroo Bay and Susan's Bay, there is a little harbour where small boats trades internationally with neighbouring Guinea. This trade is so developed that the International Organisation for Migration had an office inside the settlement during the Ebola outbreak in 2014-15.

Another example are imported second-hand clothes from all over the globe sold locally through a complex system of traders who select them, adjust/improve them to fit with local fashion trends and sell them to customer from the appropriate income group. Even people in the lowest stages of livelihood sectors are aware that the tools they buy come from China and are thus conscious of their sector being part of an international process.

\section{What the informal does?}

Informality is often described as a "lack of", an inverted mirror of formality. What our research demonstrates is instead that these "informal" livelihoods sectors provide what the formal sector and the state are unable to do, and what they lack: employment and strong networks of trust and mutual assistance relationships.

The type of employment produced through the livelihood sectors of informal settlement residents has two fundamental characteristics: it is labour intensive, and offers an ease of entry for the very poor. In general, the technology of production prioritises the use of labour rather than substituting it with capital-intensive productive processes. This maximises employment, which does not require a high level of skills training, performing a fundamental social function that supports the wellbeing of an expanding urban population.

Some stages of these value chains are 'open' (based on common property resources with relatively open access) and entry into the sector easy, as it is based on fairly limited tools and skills. As one stone quarrier in Moyiba observed: "Everybody is free to use the quarry. You only need to declare yourself to the existing members and they will willingly indoctrinate you". This means that a wide range of people can engage in these productive activities as a coping mechanism. However, this ease of entry also means that competition is high and thus income levels are low, with many participants only earning enough to subsist.

In many cases people entered the low stages of these sectors when they faced challenges in life (death of parent, failure of a business, loss of employment, school dropout, and teenage pregnancy). The sectors also involve effective systems of mutual social protection to cope with the high level of uncertainty. These can be horizontal such as saving groups, or vertical cash advances from brokers in exchange of loyalty. In this sense, these sectors contribute to build a social protection of last resort.

The contribution of these sectors goes beyond providing a livelihood to those involved. They allow "formal" economic activities to be viable, particularly in the absence of state capacity to adequately regulate and promote economic activities. For example, these sectors provide 
the construction industry with materials such as stones and sand. These sectors also contribute to a number of broader objectives, by offering employment to a large number of young people, they support social cohesion, help diffuse social conflict, and prevent violence (Finn \& Oldfield, 2015).

The state antagonistic role towards the livelihoods of informal settlement residents is well documented across many African cities like Kigali (Finn, 2018), Kampala (Lindell, Ampaire, \& Byerley, 2019), Nairobi (Thieme, 2018), Dar Es Salaam (Brown, 2015). Therefore, demonstrating what the informal sector does for the city is an important step towards changing policy responses in African cities. We also deconstruct with context-specific evidence other entrenched ideas about the in-formal that, despite having been partially challenged in the broader scholarship, are still predominant in policy circles and negatively affect the success of these livelihood sectors and the city economy.

\section{Governing the informal and using the informal to govern}

The notion that the informal is not rule-based, structured, and predictable and that it is beyond the reach of official governance processes is challenged by our research. While most economic sectors in Sierra Leone lack state monitoring, livelihood sectors of informal settlement residents have highly complex social organisation of labour with internal regulation processes and mechanisms to deal with shocks and increases in demand. As pointed out by McFarlane and Waibel (2012, p. 2),

"Informal institutions can replace [...] formal ones in contexts where the state is unable or unwilling to implement its formal rules. In this sense, informality contributes to formal institutions by organising social interaction in the absence of the state, for example, during periods of rapidly changing socio-economic contexts, rapid urban development..."

In the context of post-civil war Sierra Leone with the state slowing developing its capacity, different types of collective action become autonomous processes of self-governance to fill state's gaps. Wealthy people have agreements with politicians and government officials to breach formal processes, for example, regarding land use and building permits. Similarly, established businesses may have a set of practices that do not follow official governance processes. It is important to state that activities "beyond the reach of official governance processes" does not necessarily mean these are areas where the government is not present. Instead, it includes arrangements with government officials who sometimes explicitly and sometimes tacitly authorise the development. In this sense, applying this notion of informality also means that a lot of what the state itself does is informal as argued up by Meagher (2007).

The livelihoods sectors where informal settlement residents work establish self-managed informal institutions with complex and evolving regulations that fill gaps from the state. These institutions regulate and enable the operations of these sectors, for instance through local by-laws on mining and fines whose revenues are used to improve shared road infrastructures. These forms of autonomous collective action creates horizontal bonds and trusts which is a further enabler of these sectors because they operate in a cash scarce system and therefore transactions take place on trust that people will be paid. 
It is also important to understand the political use of "in/formality", by examining how informality and formality are deployed to produce and challenge urban inequalities (McFarlane \& Waibel, 2012, p. 7). For example, planners label some illegal activities as informal, while other illegal activities are accepted (Roy, 2009). In this regard, our research demonstrates how inappropriate it is to frame informality as the practice of the poor and formality as the practice of the wealthy (see for instance the landslide of 2017 mentioned above which destroyed an informal settlement in which the houses of several senior politicians had been built), and challenges the idea that formality and informality are located in distinct spaces of the city.

"While this type of informality of the poor is criminalised, informality of the rich may be ignored or even incentivised. Some high-income developments are also informal from the point of view of planning regulations in that they are built without permits in areas that are not zoned for residential development, against the Master Plan, and often with infrastructure that does not align with city plans. Despite these infractions however, these developments are not criminalised. This double standard is based on dangerous discourses around the urban poor" (Rigon et al., 2018, p. 421).

\section{Conclusion}

This paper argues that it is inaccurate to frame informality as belonging to the poor. The paper also challenges the idea that formality and informality are part of clearly defined different spaces or economic activities in the city, by demonstrating the presence of informality in a wide range of economic activities normally labelled as formal and the way in which informal activities are organically part of complex value chains across the entire city and internationally.

We argue that understanding the hybridity of in/formality as part of urban practices undertaken by all actors across the city is a necessary step in the construction of an African urbanism that values and acknowledges existing urban realities, and which can underpin cities' development strategies. The label of informality should not be politically applied to justify the elimination of "less desirable" economic activities which we have demonstrated to be the backbone of the city. The in-formal divide often "obscures sets of power relations" (Marx \& Kelling, 2019, p. 496). Going beyond the divide and demonstrating the relational nature of the connections between the livelihoods of the residents of informal settlements and the broader city economy means that latent power relations can be addressed. It is not possible to improve the wellbeing of those working in informal economic activities without assessing the rest of the economy and how it is inherently intertwined with the livelihoods of informal settlement residents.

Our analysis of the "informality of the poor" in Freetown demonstrates what it does. In the context of a post-conflict fragile state, social protection, employment and livelihoods are critical for the stability of the capital city and ultimately the entire country, and thus fundamental to the wellbeing of Sierra Leone. Moreover, unlike widespread discourses of these activities as being unregulated and ungoverned, they are highly regulated through complex and hybrid governance system which play a fundamental social and economic function, particular in light of the limited capacity of the state to offer appropriate governance. The paradox is that "contemporary urban development actively undermines the very kinds of experiences, histories and relationships from which to substantialise the livelihoods of 
expanding urban populations" (Simone \& Pieterse, 2017, p. 9). We are aware that some of these livelihoods sectors are based on the exploitation of finite natural resources and, as a result, have little room for expansion or little ability to provide livelihoods for the growing populations of the case study settlements.

Deconstructing dominant policy discourses and providing evidence of what these informal economic activities do is a necessary step to debunk myths about building modern and productive cities by curbing the livelihood activities of informal settlement residents. These activities are the "lifeblood" of many African cities, making significant contributions to the economy, supporting local value chains and global exchange (Mitlin \& Roever, 2016). Achieving the Sustainable Development Goal 11 (Making cities and human settlements inclusive, safe, resilient and sustainable) requires a change in the policy discourse around informality to recognise residents of informal settlements, their economic activities, their settlements, and the contributions they make. This is a shift in policy from criminalisation and curbing towards creating an enabling environment for these activities.

Policies, regulations, and interventions affecting these sectors should be carefully thought out and aimed at providing better labour intensive alternatives, particularly regarding working conditions and social protection, rather than undermining existing livelihoods. Urban planning and economic strategies should be developed through open policy dialogues with the participation of residents of informal sectors and the organisations that support them. National policy interventions in these sectors should carefully consider all stakeholders to ensure the most vulnerable are not adversely affected by proposed changes. Most NGO support focuses on the individual, making a crucial contribution, but misses strategic settlement and city scale interventions. NGOs could also participate in developing alternative labour intensive sectors that are not reliant on finite natural resources; supporting settlement-scale governance of livelihoods and the use of natural resources; and engaging informal settlements in city-scale economic planning.

\section{References}

Abdullah, I. (2002). Youth culture and rebellion: Understanding Sierra Leone's wasted decade. Critical Arts, 16(2), 19-37. doi:10.1080/02560240285310121

Acuto, M., Dinardi, C., \& Marx, C. (2019). Transcending (in)formal urbanism. Urban Studies, 56(3), 475-487. doi:10.1177/0042098018810602

Banks, N., Lombard, M., \& Mitlin, D. (2019). Urban Informality as a Site of Critical Analysis. The Journal of Development Studies, 1-16. doi:10.1080/00220388.2019.1577384

Bhan, G. (2009). "This is no longer the city I once knew". Evictions, the urban poor and the right to the city in millennial Delhi. Environment and Urbanization, 21(1), 127-142. doi:10.1177/0956247809103009

Brown, A. (2015). Claiming the Streets: Property Rights and Legal Empowerment in the Urban Informal Economy. World Development, 76, 238-248. doi:https://doi.org/10.1016/i.worlddev.2015.07.001

Brown, A., Lyons, M., \& Dankoco, I. (2010). Street Traders and the Emerging Spaces for Urban Voice and Citizenship in African Cities. Urban Studies, 47(3), 666-683. doi:10.1177/0042098009351187

Dodman, D., Goosen, H. J., Rusca, M., \& Colenbrander, S. (2016). African Urbanisation and Urbanism: Implications for risk accumulation and reduction. Working paper. Urban Africa Risk Knowledge. 
Enria, L. (2018). The Politics of Work in a Post-Conflict State: Youth, Labour \&amp; Violence in Sierra Leone: Boydell \& Brewer.

Farha, L. (2011). Forced Evictions: Global Crisis, Global Solutions. Nairobi: UN-HABITAT. Retrieved from Nairobi:

Finn, B. (2018). Quietly Chasing Kigali: Young Men and the Intolerance of Informality in Rwanda's Capital City. Urban Forum, 29(2), 205-218. doi:10.1007/s12132-017-9327$y$

Finn, B., \& Oldfield, S. (2015). Straining: Young Men Working through Waithood in Freetown, Sierra Leone. Africa Spectrum, 50(3), 29-48.

Freetown City Council. (2016). Freetown City Development Plan Retrieved from Freetown:

Ghertner, D. A. (2011). Rule by Aesthetics: World-Class City Making in Dehli. In A. Roy \& A. Ong (Eds.), Worlding Cities: Asian Experiments and the Art of Being Global (pp. 279306). Malden, Oxford: Wiley-Blackwell.

Guha-Khasnobis, B., Kanbur, S. M. R., \& Ostrom, E. (2006). Beyond Formality and Informality. In B. Guha-Khasnobis, S. M. R. Kanbur, \& E. Ostrom (Eds.), Linking the formal and informal economy: concepts and policies (pp. 1-18). Oxford: Oxford University Press.

ILO. (2002). Women and Men in the Informal Economy: A Statistical Picture. Retrieved from Geneva:

ILO. (2018). Women and Men in the Informal Economy: a Statistical Picture. Retrieved from Geneva:

Kamete, A. Y. (2012). Interrogating planning's power in an African city: Time for reorientation? Planning Theory, 11(1), 66-88. doi:10.1177/1473095211419116

Lees, L., Shin, H. B., \& López-Morales, E. (2016). Planetary gentrifications: Uneven development and displacement. Bristol: Polity Press.

Lindell, I., Ampaire, C., \& Byerley, A. (2019). Governing urban informality: re-working spaces and subjects in Kampala, Uganda. International Development Planning Review, 41(1), 63-84.

Marx, C., \& Kelling, E. (2019). Knowing urban informalities. Urban Studies, 56(3), 494-509. doi:10.1177/0042098018770848

McFarlane, C. (2012). Rethinking Informality: Politics, Crisis, and the City. Planning Theory \& Practice, 13(1), 89-108. doi:10.1080/14649357.2012.649951

McFarlane, C. (2019). Thinking with and beyond the informal-formal relation in urban thought. Urban Studies, 56(3), 620-623. doi:10.1177/0042098018810603

McFarlane, C., \& Waibel, M. (2012). Urban informalities: reflections on the formal and informal. Farnham: Ashgate.

Meagher, K. (2007). Introduction: Special Issue on 'Informal Institutions and Development in Africa'. Africa Spectrum, 42(3), 405-418. doi:https://www.jstor.org/stable/40175202

Mitlin, D., \& Roever, S. (2016). Enhancing Productivity in the Urban Informal Economy: Cardiff University,

WIEGO,

UN-Habitat.

Mitlin, D., \& Satterthwaite, D. (Eds.). (2004). Empowering Squatter Citizen: Local Government, Civil Society, and Urban Poverty Reduction. London: Earthscan.

Myers, G. A. (2010). Seven Themes in African Urban Dynamics. Retrieved from Uppsala:

Oliver-Smith, A. (2010). Defying displacement: grassroots resistance and the critique of development. Austin, TX: University of Texas Press.

Palat Narayanan, N., \& Véron, R. (2018). Informal production of the city: Momos, migrants, and an urban village in Delhi. Environment and Planning D: Society and Space, 36(6), 1026-1044. doi:10.1177/0263775818771695

Pieterse, E. A., \& Simone, A. M. (2013). Rogue urbanism: emergent African cities: Jacana Media.

Pratt, A. (2019). Formality as exception. Urban Studies, 56(3), 612-615. doi:10.1177/0042098018810600 
Rigon, A., Koroma, B., Macarthy, J., \& Apsan Frediani, A. (2018). The politics of urban management and planning in African cities. In T. Binns, K. Lynch, \& E. Nel (Eds.), The Routledge handbook of African development (pp. 415-425). New York: Routledge.

Roy, A. (2005). Urban Informality: Toward an Epistemology of Planning. Journal of the American Planning Association, 71(2), 147-158. doi:10.1080/01944360508976689

Roy, A. (2009). Strangely familiar: planning and the worlds of insurgence and informality. Planning Theory, 8(1), 7-11. doi:10.1177/1473095208099294

Simone, A. M., \& Pieterse, E. A. (2017). New urban worlds: inhabiting dissonant times (1 ed.). Cambridge, UK; Malden, MA: Polity.

Smith, N. (1996). The New Urban Frontier: Gentrification and the Revanchist City. . London: Routledge.

Statistics Sierra Leone. (2015). Population and Housing Census Retrieved from Freetown:

Thieme, T. A. (2018). The hustle economy:Informality, uncertainty and the geographies of getting by. Progress in Human Geography, 42(4), 529-548. doi:10.1177/0309132517690039

UN-Habitat. (2003). The challenge of slums: global report on human settlements 2003. London: Earthscan.

United Nations Statistics Division. (2015). Millennium Development Goals Indicators Report 2014. Retrieved from https://mdgs.un.org/unsd/mdg/SeriesDetail.aspx? srid=711

Watson, V. (2009). 'The planned city sweeps the poor away...': Urban planning and 21st century urbanisation. Progress in Planning, 72(3), 151-193. doi:https://doi.org/10.1016/j.progress.2009.06.002

Watson, V. (2014). African urban fantasies: dreams or nightmares? Environment and Urbanization, 26(1), 215-231. doi:doi:10.1177/0956247813513705

Williams, C. C., \& Lansky, M. A. (2013). Informal employment in developed and developing economies: Perspectives and policy responses. International Labour Review, 152(34), 355-380. doi:doi:10.1111/j.1564-913X.2013.00196.x

World Bank. (2013). Sierra Leone Social Protection Assessment. Retrieved from Washington DC: 